\title{
REVIEWS
}

The Hill of Light. G. D. Adams. Constable and Co. 12s. $6 d$.

This is a story book, the story of the mammals and birds of a Welsh hillside. It glances at the human inhabitants, too, but only when they break into the cycle of animal life, usually to the disadvantage of the animal.

The story is centred on Grey the badger, but the life-histories of Fang the fox, Mulo the buzzard, and many other wild creatures are well portrayed. The thoughts of men are translated into the minds of animals, but not too much so for a book of this kind. There is no attempt at happy endings, but the book is not overloaded with tragedy, and utter disaster does not befall any of the creatures which have especially gained our sympathy. The only illustration is an excellent picture of a badger.

I would recommend this book to a boy or girl of 12 to 15 , for which range of age it is presumably intended. Although it is not free from inaccuracies-for instance a great grey shrike is described as rather larger than a jay-it should serve to arouse any latent interest in natural history.

\section{L. B.}

The Ancient Wiite Cattle of Britain and their Descen-

Dants. G. Kenneth Whitehead. Faber and Faber, Ltd. $63 s$.

Mr. Whitehead's book supersedes Storer's Wild White Cattle of Great Britain, published in $\mathbf{1 8 7 7}$, which is seriously out of date. He enumerates as many as $\mathbf{9 7}$ herds, gives descriptions of all of them, though particularly of those of Chillingham, Cadzow, Chartley, Vaynol and Dynevor. These are precisely the ones of particular interest from the point of view of fauna preservation, for some have been claimed to be more or less direct descendants of the wild ancestor of all cattle, the aurochs (Bos primigenius Boj.).

The possible origins of white cattle and their relations with the aurochs are summarized mainly from the existing literature. In weighing the evidence for a direct descent from the aurochs on the one hand and for a deviation from Roman cattle or similar continental stock, the author inclines towards the latter alternative. In this respect it is to be regretted that the bibliography does not contain a single reference to a continental publication on the origin of cattle. The back-breeding experiments of the brothers Heck, however, are discussed. 
In the chapter on the aurochs, the small Neolithic cattle, Bos longifrons, is regarded as a separate species, whilst the alternative view that it is a domestication product has long been held also. Reading this chapter one realizes how little is really known and how much a large-scale osteological study of recent breeds, archaeological material and fossils is needed.

In discussing the white colour, Mr. Whitehead holds the view that this tends to be dominant over other colours. Breeding statistics suggest in part that this may be so. There would have been plenty of time since the Roman period or even earlier for whiteness to establish itself. Since the twelfth century, some breeders appear to have taken a fancy to white breeds and to have selected white specimens, killing off others. To-day the Cadzow herd produces 23 per cent black calves, 29 per cent incorrectly marked ones, and 48 per cent correctly marked, i.e. virtually white calves. The problem of coloration, however, appcars to be more complicated than this. The wild aurochs stock possessed white individuals, some even spotted with black and with markings much like those of British white cattle. The evidence for this is provided by the wonderful prehistoric paintings of Lascaux in France, not mentioned by Mr. Whitehead ; these might be adduced in support of a rather more direct descent of the British white cattle from the aurochs than the author is prepared to admit.

The bulk of the book consists of the recorded history of the various herds. For this compilation, made at a time when it was still possible to obtain the information, the author deserves the highest praise. His book will have to be consulted by everyone interested in the breeding of white cattle in this country as well as by those concerned with the evolution of domesticated breeds.

A special chapter is devoted to the modern white breed, the "British Whites". It is intensely interesting from our point of view for it shows how the requirements of breeders' societies can impress a new label on an animal in a short time. They are expected to exhibit the best combination of milk and meat qualities, and must be hornless. Since 1947 horned white cattle can no longer be registered in the Herd Book, whilst no matter how overmarked a beast may be, provided it is partly of registered British White blood, it may be entered. Whilst this is a laudable effort to produce an economically worth while breed, such policy does not encourage those stalwart park owners who with enthusiasm and at great expense, have continued to keep alive the primitive stock which the horned white cattle of Britain undoubtedly 
represent. Their value to science is sufficient to justify such enterprise. Let us hope that some day an investigator finds the time (and the money) to carry out a comparative osteological investigation of these fascinating survivors from the past.

F. E. Z.

An Irisil Sanctuary. The Rev. P. G. Kennedy, S.J. At the Sign of the Three Candles, Dublin. 12s. $6 d$.

This book professes to be no more than a guide to the North Bull bird sanctuary with a list of birds likely to be seen at particular times--indeed a modest claim. In fact it is also a delightful record, clearly and simply worded, of the observations of a naturalist and bird lover.

The North Bull is a sandy island three miles long on the north side of Dublin Bay; it is in a sense man-made, for until the North Bull Wall was built it was exposed at low tide only. In 1930 it became a bird sanctuary and it still remains so, though, as Father Kennedy graphically describes in a chapter called "Violation of Sanctuary", it is under constant threat of "Development". The first threat was to join the island to the mainland by dams at both ends and thus turn the tidal mud flats, beloved of wintering duck and waders, into a Blue Lagoon. This having been found impracticable, it was proposed to turn the island itself into an Amusement Park. Though the immediate danger of even this has been averted there is no feeling of security for the future. Can it be that Eire will allow its only significant bird sanctuary to disappear?

The number of species of birds to be seen on the North Bull is at its lowest in June and July, thirty-three, rising steadily to a hundred in December and January. Then it falls off equally steadily as the year progresses. There is no temporary increase in species during either the spring or autumn migrations and it would be interesting to compare the graph of species seen throughout the year with one from a similar place on the east coast of England.

Under each species we are given interesting notes on behaviour : starlings roosting in thick matted grass on the golf course, each with a hole to itself : a collection of finches, even including bramblings, coming to the shore to feed on jettisoned wheat: a stonechat following a groundsman, perching on his spade like a robin : short-eared owls soaring like buzzards : a bar-tailed godwit coming for scraps of food.

No descriptions of birds are given in this book and presumably, therefore, the illustrations are chiefly for ornament. All the 